\title{
Article
}

\section{The Causal-Effect between Carbon Dioxide Emissions and Forestry Production and Trade: A Case Study in Ghana}

\author{
Samuel Asumadu-Sarkodie * and Phebe Asantewaa Owusu \\ Sustainable Environment and Energy Systems \\ Northern Cyprus Campus, Middle East Technical University, \\ Kalkanli, Guzelyurt, TRNC 99738/Mersin 10, Turkey; \\ phebe.owusu@metu.edu.tr \\ * Correspondence: samuelsarkodie@yahoo.com
}

\begin{abstract}
In this study, the causal-effect between carbon dioxide emissions and forestry production and trade was investigated in Ghana by employing a data spanning from 1961 to 2014 by using the VECM and ARDL model. Evidence of the long-run equilibrium relationship in the VECM shows that, a $1 \%$ increase in veneer sheet production reduces carbon dioxide emissions by $1.47 \%$ in the long-run. There was evidence of a bidirectional causality between carbon dioxide emissions and veneer sheet production, carbon dioxide emissions and wood charcoal production, and a unidirectional causality running from carbon dioxide emissions to wood fuel production and plywood production to carbon dioxide emissions. Evidence from the long-run equilibrium relationship in the ARDL model shows that; a 1\% increase in plywood production will increase carbon dioxide emissions by $0.17 \%$ in the long-run, a $1 \%$ increase in sawnwood production will increase carbon dioxide emissions by $0.17 \%$ in the long-run, a $1 \%$ increase in wood charcoal production will increase carbon dioxide emissions by $0.36 \%$ in the long-run and a $1 \%$ increase in wood fuel production will increase carbon dioxide emissions by $0.37 \%$ in the long-run.
\end{abstract}

Keywords: forestry production; carbon dioxide emissions; ARDL; Granger-causality; Ghana; econometrics

JEL Classifications: Q40, Q23 


\section{Introduction}

Greenhouse gas emissions have become a global concern which has attracted attention from researchers and policy makers within the last decades [1-6]. According to UN-REDD [7], "deforestation and forest degradation, through agricultural growth, conversion to pastureland, infrastructure development, destructive logging, fires, and among others, account for nearly $20 \%$ of world greenhouse gas emissions, more than the whole international transportation sector and second solely to the energy sector. It is now clear that in order to constrain the impacts of climate amendment among limits that society can reasonably be able to tolerate, the worldwide average temperatures should be stabilized at intervals $2{ }^{\circ} \mathrm{C}$. This will be practically not possible to attain while not reducing emissions from the forest sector, in addition to different mitigation actions".

Illegal chainsaw operators have played a role in Ghana's deforestation accounting for a deforestation rate of 65,000 hectares per annum, in addition, the illegal chain saw milling accounts for $84 \%$ of Ghana's annual lumber supply of $497,000 \mathrm{~cm}^{3}$ and a market value of more than US\$ 200 million [8]. Due to illegal chainsaw, Ghana's estimated forest reserve that stood at 8.2 million hectares in the $20^{\text {th }}$ century has eventually dropped to 1.6 million hectares $[8,9]$. Nevertheless, the environmental pollution and the impact of the deforestation in Ghana has not been investigated to the best of our knowledge.

Accordingly, the study aims at analysing the causal-effect between carbon dioxide emissions and forestry production and trade: a case study in Ghana. Previous studies examined the relationship between carbon dioxide emissions, energy consumption, population and GDP in Ghana $[10,11]$ while another study focused on the causal nexus between carbon dioxide emissions and agriculture in Ghana [12]. In both cases, there were evidence of a long-run equilibrium relationship between carbon dioxide emissions and environmental pollution in 
Ghana. Nevertheless, the current study makes an attempt to examine the role of forestry production and trade in environmental pollution by employing a time series data spanning from 1961-2014 by employing both Vector error correction and ARDL models. As a contribution to literature, the study employs the Kendall's tau-b correlation and bootstrapping test for nonparametric and parametric estimates to examine the strength of association in the descriptive statistical analysis. In addition, the study examines the random innovations of variables in the VAR by employing the Cholesky impulse-response test. The study will increase the global debate on the role of forestry production and trade in environmental pollution from the Ghana case. Significantly, the study will serve as an information tool for future national policies, strategies and planning in Ghana while playing a role in climate change mitigation and sustainable development.

The remainder of the study consists of "Methodology", "Results and Discussion", "Conclusion and Policy Recommendations".

\section{Methodology}

The study examines the causal-effect between carbon dioxide emissions and forestry production and trade: a case study in Ghana by using both Vector Error Correction Model (VECM) and Autoregressive Distributed Lag (ARDL) model. A time series data spanning from 1961 to 2014 were employed from the FAO database [13]. Eight variables were used in the study which comprise; CO2 - Carbon dioxide emissions (kt), WC-Wood Charcoal Production (Tonnes), SV-Sawlogs \& Veneer Logs Production (Tonnes), WF-Wood Fuel Production (Tonnes), S-Sawnwood Production (Tonnes), VS-Veneer Sheets Production (Tonnes), PPlywood Production (Tonnes) and WBP-Wood-Based Panels Production (Tonnes). 


\section{Descriptive Statistical Analysis}

The study examines the characteristics of the datasets before proceeding to the model estimation. Table 1 presents the descriptive statistical analysis of the study variables. Evidence from Table 1 shows that $\mathrm{S}$ and $\mathrm{SV}$ are negatively skewed while $\mathrm{CO} 2, \mathrm{P}, \mathrm{WBP}, \mathrm{WC}$ and $\mathrm{WF}$ have a long-right tail (positive skewness). While $\mathrm{CO} 2, \mathrm{SV}, \mathrm{WBP}, \mathrm{WC}$ and WF exhibit a platkurtic distribution, S and P exhibit a leptokurtic distribution. The Jarque-Bera statistic test shows that CO2, P, VS, WBP and WF are not normally distributed. As a result, logarithmic transformation is applied to have a more stable data variance. At this moment, let LCO2, LP, LS, LSV, LVS, LWBP, LWC and LWF represent the logarithmic transformation of CO2, P, S, SV, VS, WBP, WC and WF. Table 2 presents the Kendall's tau-b correlation test with bootstrap results based on 1000 bootstrap samples. Evidence from Table 2 shows that with the exception of LSV, the linear relationship between the dependent variable (LCO2) and the independent variables (LP, LS, LVS, LWBP, LWC and LWF) are significant at $1 \%$ with less than $1 \%$ reported standard error and $0.3 \%$ bias reported by the bootstrap. It is evident from Table 2 that the correlation coefficient for the relationship between LCO2 and all the variables is less than 0.90 which indicates a less possibility of multicollinearity among the study variables. Fig. 1 shows the trend of the variables. 

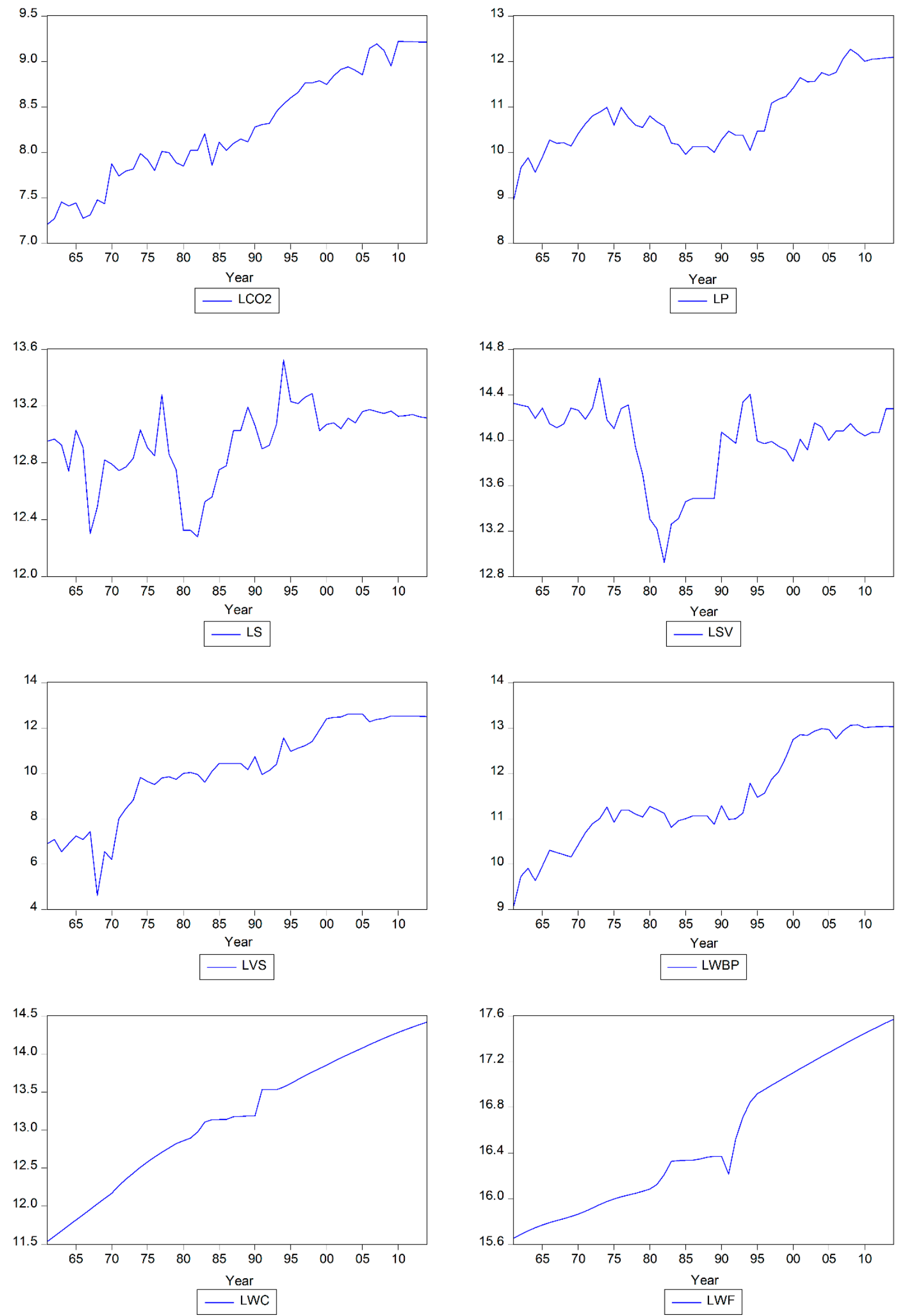

Fig. 1. Trend of Variables 
Table 1. Descriptive Analysis

\begin{tabular}{lllllllll}
\hline Statistic & CO2 & P & S & SV & VS & WBP & WC & WF \\
\hline Mean & 4693.149 & 66759.26 & 433581.5 & 1244833 & 93783.33 & 165116.7 & 709758.9 & 18177603 \\
Median & 3397.476 & 40000 & 455000 & 1295000 & 29500 & 70250 & 528000 & 12495500 \\
Maximum & 10102.59 & 213000 & 747000 & 2076000 & 300000 & 474000 & 1829309 & 42719574 \\
Minimum & 1345.789 & 7800 & 215000 & 410000 & 100 & 8800 & 102110 & 6286000 \\
Std. Dev. & 2828.331 & 56202.12 & 107018.9 & 363886.9 & 112417.9 & 167160.8 & 517553.7 & 11522437 \\
Skewness & 0.6982 & 1.1804 & -0.067 & -0.4595 & 0.8713 & 0.9078 & 0.6628 & 0.7296 \\
Kurtosis & 2.1545 & 3.0444 & 3.3176 & 2.7265 & 1.9637 & 2.0372 & 2.2076 & 2.0764 \\
Jarque- & 5.9964 & 12.545 & 0.2674 & 2.0687 & 9.2493 & 9.5034 & 5.3668 & 6.7103 \\
Bera & & & & & & & & \\
Probability & 0.0499 & 0.0019 & 0.8748 & 0.3555 & 0.0098 & 0.0086 & 0.0683 & 0.0349 \\
\hline
\end{tabular}


Table 2. Kendall's Tau-b Correlation and Bootstrapping

\begin{tabular}{|c|c|c|c|c|c|c|c|c|c|c|c|c|}
\hline \multirow{3}{*}{\multicolumn{2}{|c|}{$\begin{array}{l}\text { Kendall's LCO2 } \\
\text { tau_b }\end{array}$}} & & & & $\mathrm{LCO} 2$ & LP & LS & LSV & LVS & LWBP & LWC & LWF \\
\hline & & \multicolumn{3}{|c|}{ Correlation Coefficient } & 1.000 & $.557^{* *}$ & $.454^{* *}$ & -.104 & $.790^{* *}$ & $.748^{* *}$ & $.899^{* *}$ & $.889^{* *}$ \\
\hline & & \multicolumn{3}{|c|}{ Sig. (2-tailed) } & & .000 & .000 & .266 & .000 & .000 & .000 & .000 \\
\hline & & \multicolumn{3}{|l|}{$\mathrm{N}$} & 54 & 54 & 54 & 54 & 54 & 54 & 54 & 54 \\
\hline & & \multirow[t]{4}{*}{ Bootstrap $^{c}$} & \multicolumn{2}{|l|}{ Bias } & 0.000 & .003 & -.001 & .002 & .000 & .002 & .000 & .000 \\
\hline & & & \multicolumn{2}{|l|}{ Std. Error } & 0.000 & .083 & .058 & .096 & .036 & .050 & .023 & .025 \\
\hline & & & \multirow{2}{*}{\multicolumn{2}{|c|}{$\begin{array}{ll}95 \% & \text { Lower } \\
\text { Confidence } & \text { Upper } \\
\text { Interval } & \end{array}$}} & 1.000 & .381 & .340 & -.279 & .714 & .637 & .849 & .835 \\
\hline & & & & & 1.000 & .700 & .570 & .103 & .856 & .834 & .940 & .933 \\
\hline & \multirow[t]{7}{*}{ LP } & \multicolumn{3}{|c|}{ Correlation Coefficient } & $.557^{* *}$ & 1.000 & $.302^{* *}$ & .001 & $.493^{* *}$ & $.721^{* *}$ & $.580^{* *}$ & $.567^{* *}$ \\
\hline & & \multicolumn{3}{|c|}{ Sig. (2-tailed) } & .000 & & .001 & .994 & .000 & .000 & .000 & .000 \\
\hline & & \multicolumn{3}{|l|}{$\mathrm{N}$} & 54 & 54 & 54 & 54 & 54 & 54 & 54 & 54 \\
\hline & & \multirow[t]{4}{*}{ Bootstrap $^{c}$} & \multicolumn{2}{|l|}{ Bias } & .003 & 0.000 & .001 & .005 & .003 & .001 & .002 & .002 \\
\hline & & & \multicolumn{2}{|l|}{ Std. Error } & .083 & 0.000 & .082 & .099 & .081 & .072 & .096 & .100 \\
\hline & & & \multirow{2}{*}{\multicolumn{2}{|c|}{$\begin{array}{ll}95 \% & \text { Lower } \\
\text { Confidence } & \text { Upper } \\
\text { Interval } & \end{array}$}} & .381 & 1.000 & .140 & -.187 & .333 & .562 & .385 & .360 \\
\hline & & & & & .700 & 1.000 & .462 & .204 & .646 & .849 & .753 & .745 \\
\hline & \multirow[t]{7}{*}{$\mathrm{LS}$} & \multicolumn{3}{|c|}{ Correlation Coefficient } & $.454^{* *}$ & $.302^{* *}$ & 1.000 & .115 & $.442^{* *}$ & $.430^{* *}$ & $.430^{* *}$ & $.432^{* *}$ \\
\hline & & \multicolumn{3}{|c|}{ Sig. (2-tailed) } & .000 & .001 & & .224 & .000 & .000 & .000 & .000 \\
\hline & & \multicolumn{3}{|l|}{$\mathrm{N}$} & 54 & 54 & 54 & 54 & 54 & 54 & 54 & 54 \\
\hline & & \multirow[t]{4}{*}{ Bootstrap $^{c}$} & Bias & & -.001 & .001 & 0.000 & -.002 & .001 & .002 & -.001 & -.001 \\
\hline & & & \multicolumn{2}{|l|}{ Std. Error } & .058 & .082 & 0.000 & .112 & .056 & .065 & .061 & .062 \\
\hline & & & \multirow{2}{*}{\multicolumn{2}{|c|}{$\begin{array}{ll}95 \% & \text { Lower } \\
\text { Confidence } & \text { Upper } \\
\text { Interval } & \end{array}$}} & .340 & .140 & 1.000 & -.110 & .334 & .296 & .310 & .307 \\
\hline & & & & & .570 & .462 & 1.000 & .326 & .554 & .557 & .547 & .552 \\
\hline & \multirow[t]{2}{*}{ LSV } & \multicolumn{3}{|c|}{ Correlation Coefficient } & -.104 & .001 & .115 & 1.000 & -.137 & -.089 & -.121 & -.128 \\
\hline & & \multicolumn{3}{|c|}{ Sig. (2-tailed) } & .266 & .994 & .224 & & .145 & .347 & .199 & .172 \\
\hline
\end{tabular}




\begin{tabular}{|c|c|c|c|c|c|c|c|c|c|c|c|}
\hline & \multicolumn{3}{|l|}{$\mathrm{N}$} & 54 & 54 & 54 & 54 & 54 & 54 & 54 & 54 \\
\hline & \multirow[t]{4}{*}{ Bootstrap $^{c}$} & \multicolumn{2}{|l|}{ Bias } & .002 & .005 & -.002 & 0.000 & .003 & .005 & .003 & .003 \\
\hline & & \multicolumn{2}{|l|}{ Std. Error } & .096 & .099 & .112 & 0.000 & .092 & .095 & .103 & .102 \\
\hline & & & -.279 & -.187 & -.110 & 1.000 & -.309 & -.261 & -.312 & -.313 \\
\hline & & \multicolumn{2}{|c|}{$\begin{array}{l}\text { Confidence Upper } \\
\text { Interval }\end{array}$} & .103 & .204 & .326 & 1.000 & .071 & .113 & .105 & .095 \\
\hline \multirow[t]{7}{*}{ LVS } & \multicolumn{3}{|c|}{ Correlation Coefficient } & $.790^{* *}$ & $.493^{* *}$ & $.442^{* *}$ & -.137 & 1.000 & $.776^{* *}$ & $.828^{* *}$ & $.837^{* *}$ \\
\hline & \multicolumn{3}{|c|}{ Sig. (2-tailed) } & .000 & .000 & .000 & .145 & & .000 & .000 & .000 \\
\hline & \multicolumn{3}{|l|}{$\mathrm{N}$} & 54 & 54 & 54 & 54 & 54 & 54 & 54 & 54 \\
\hline & \multirow[t]{4}{*}{ Bootstrap $^{c}$} & \multicolumn{2}{|l|}{ Bias } & .000 & .003 & .001 & .003 & 0.000 & .002 & .000 & .000 \\
\hline & & \multicolumn{2}{|l|}{ Std. Error } & .036 & .081 & .056 & .092 & 0.000 & .040 & .032 & .031 \\
\hline & & \multirow{2}{*}{\multicolumn{2}{|c|}{$\begin{array}{ll}95 \% & \text { Lower } \\
\text { Confidence } & \text { Upper } \\
\text { Interval } & \end{array}$}} & .714 & .333 & .334 & -.309 & 1.000 & .692 & .764 & .773 \\
\hline & & & & .856 & .646 & .554 & .071 & 1.000 & .852 & .888 & .894 \\
\hline \multirow[t]{7}{*}{ LWBP } & \multicolumn{3}{|c|}{ Correlation Coefficient } & $.748^{* *}$ & $.721^{* *}$ & $.430^{* *}$ & -.089 & $.776^{* *}$ & 1.000 & $.793^{* *}$ & $.797^{* *}$ \\
\hline & \multicolumn{3}{|c|}{ Sig. (2-tailed) } & .000 & .000 & .000 & .347 & .000 & & .000 & .000 \\
\hline & \multicolumn{3}{|l|}{$\mathrm{N}$} & 54 & 54 & 54 & 54 & 54 & 54 & 54 & 54 \\
\hline & \multirow[t]{4}{*}{ Bootstrap $^{c}$} & \multicolumn{2}{|l|}{ Bias } & .002 & .001 & .002 & .005 & .002 & 0.000 & .002 & .002 \\
\hline & & \multicolumn{2}{|l|}{ Std. Error } & .050 & .072 & .065 & .095 & .040 & 0.000 & .052 & .051 \\
\hline & & $95 \%$ & Lower & .637 & .562 & .296 & -.261 & .692 & 1.000 & .682 & .686 \\
\hline & & $\begin{array}{l}\text { Confidence } \\
\text { Interval }\end{array}$ & Upper & .834 & .849 & .557 & .113 & .852 & 1.000 & .884 & .887 \\
\hline \multirow[t]{7}{*}{ LWC } & \multicolumn{3}{|c|}{ Correlation Coefficient } & $.899^{* *}$ & $.580^{* *}$ & $.430^{* *}$ & -.121 & $.828^{* *}$ & $.793^{* *}$ & 1.000 & $.988^{* *}$ \\
\hline & \multicolumn{3}{|c|}{ Sig. (2-tailed) } & .000 & .000 & .000 & .199 & .000 & .000 & & .000 \\
\hline & \multicolumn{3}{|l|}{$\mathrm{N}$} & 54 & 54 & 54 & 54 & 54 & 54 & 54 & 54 \\
\hline & \multirow[t]{4}{*}{ Bootstrap $^{c}$} & \multicolumn{2}{|l|}{ Bias } & .000 & .002 & -.001 & .003 & .000 & .002 & 0.000 & .000 \\
\hline & & \multicolumn{2}{|l|}{ Std. Error } & .023 & .096 & .061 & .103 & .032 & .052 & 0.000 & .013 \\
\hline & & $95 \%$ & Lower & .849 & .385 & .310 & -.312 & .764 & .682 & 1.000 & .959 \\
\hline & & $\begin{array}{l}\text { Confidence } \\
\text { Interval }\end{array}$ & Upper & .940 & .753 & .547 & .105 & .888 & .884 & 1.000 & 1.000 \\
\hline
\end{tabular}




\begin{tabular}{|c|c|c|c|c|c|c|c|c|c|c|c|}
\hline \multirow[t]{7}{*}{ LWF } & \multicolumn{3}{|c|}{ Correlation Coefficient } & $.889^{* *}$ & $.567^{* *}$ & $.432^{* *}$ & -.128 & $.837^{* *}$ & $.797^{* *}$ & $.988^{* *}$ & 1.000 \\
\hline & \multicolumn{3}{|c|}{ Sig. (2-tailed) } & .000 & .000 & .000 & .172 & .000 & .000 & .000 & \\
\hline & \multicolumn{3}{|l|}{$\mathrm{N}$} & 54 & 54 & 54 & 54 & 54 & 54 & 54 & 54 \\
\hline & \multirow[t]{4}{*}{ Bootstrap $^{c}$} & Bias & & .000 & .002 & -.001 & .003 & .000 & .002 & .000 & 0.000 \\
\hline & & Std. Error & & .025 & .100 & .062 & .102 & .031 & .051 & .013 & 0.000 \\
\hline & & $95 \%$ & Lower & .835 & .360 & .307 & -.313 & .773 & .686 & .959 & 1.000 \\
\hline & & $\begin{array}{l}\text { Confidence } \\
\text { Interval }\end{array}$ & Upper & .933 & .745 & .552 & .095 & .894 & .887 & 1.000 & 1.000 \\
\hline
\end{tabular}

**. Correlation is significant at the 0.01 level (2-tailed).

*. Correlation is significant at the 0.05 level (2-tailed).

c. Unless otherwise noted, bootstrap results are based on 1000 bootstrap samples 
Table 3. Unit Root Test

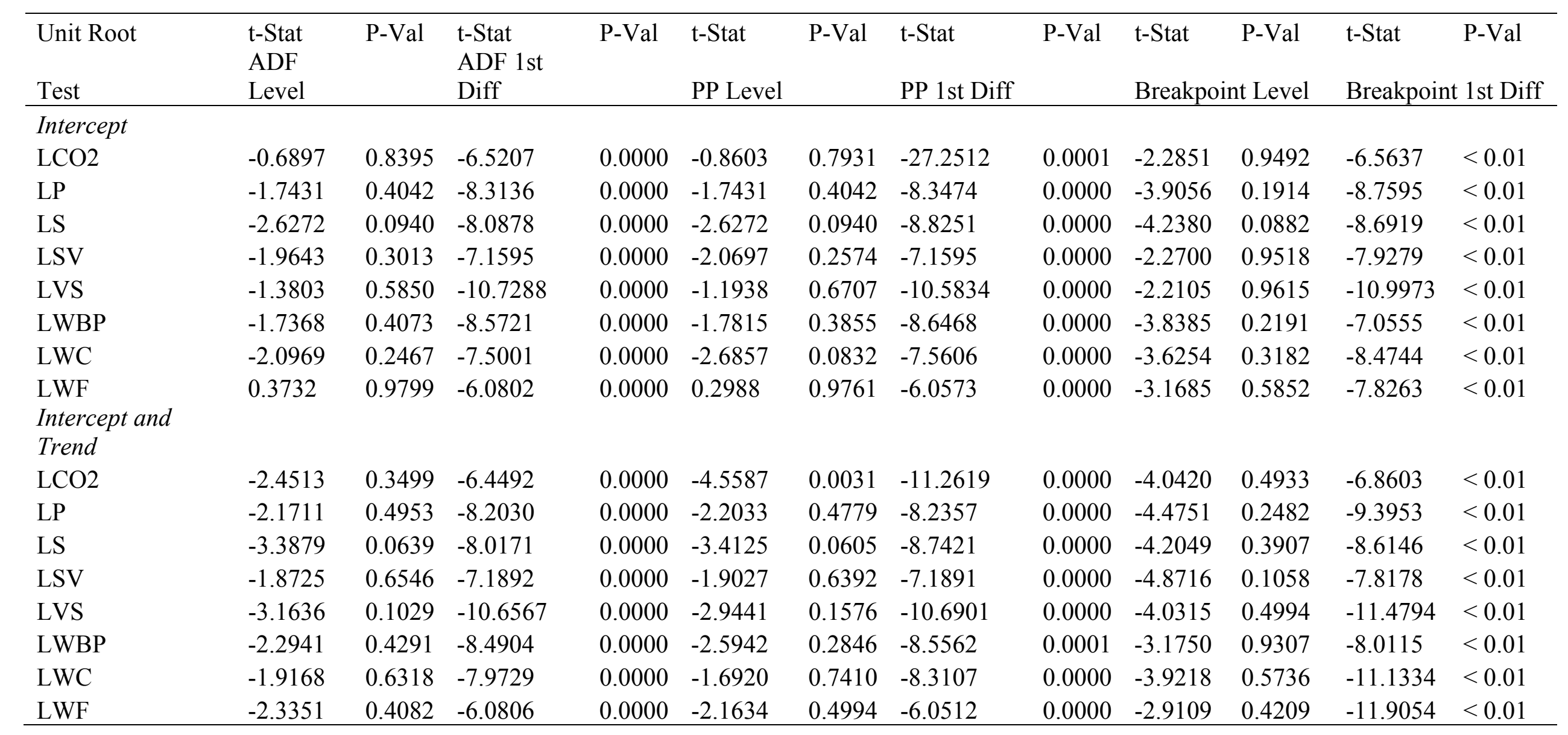


Kendall's tau-b is capable of estimating the strength of association between two ranked variables but not the causation.

\section{Unit Root Test}

To examine the causation among variables using econometric methods, the study first estimates the unit root test, which is a precondition for most co-integration techniques. The study employs the Augmented Dickey-Fuller (ADF) [14], Phillip Perron (PP) [15] and Vogelsang [16] breakpoint unit root tests. Table 3 presents the results of ADF, PP and Vogelsang's breakpoint unit root tests. Significantly, Vogelsang's breakpoint unit root test provides a robust results since it takes into consideration the innovational outlier which ADF and PP tests fail to test in the presence of structural breaks. Evidence from Table 3 shows that the null hypothesis of unit root at level cannot be rejected at 5\% significance level. Evidence from Table 3 shows that based on 5\% significance level, the null hypothesis is rejected at first difference. The ADF, PP and Vogelsang's breakpoint unit root tests suggest that the variables are integrated at I(1) which satisfies the pre-condition of Johansen's method of co-integration and the ARDL bounds test approach. 


\section{Model Estimation}

After fulfilling the pre-condition of Johansen's method of co-integration and the ARDL bounds test approach, the study follows the work of Asumadu-Sarkodie and Owusu [10],AsumaduSarkodie and Owusu [11], to estimate the VECM for the study, which is expressed as:

$\Delta\left[\begin{array}{c}L C O 2_{t} \\ L P_{t} \\ L S_{t} \\ L S V_{t} \\ L V S_{t} \\ L W B P_{t} \\ L W C_{t} \\ L W F_{t}\end{array}\right]=\left[\begin{array}{c}\alpha_{1} \\ \alpha_{2} \\ \alpha_{3} \\ \alpha_{4} \\ \alpha_{5} \\ \alpha_{6} \\ \alpha_{7} \\ \alpha_{8}\end{array}\right]+\sum_{i=1}^{p} \Delta\left[\begin{array}{c}\beta_{11 i} \beta_{12 i} \beta_{13 i} \beta_{14 i} \beta_{15 i} \beta_{16 i} \beta_{17 i} \beta_{18 i} \\ \beta_{21 i} \beta_{22 i} \beta_{23 i} \beta_{24 i} \beta_{25 i} \beta_{26 i} \beta_{27 i} \beta_{28 i} \\ \beta_{31 i} \beta_{32 i} \beta_{33 i} \beta_{34 i} \beta_{35 i} \beta_{36 i} \beta_{37 i} \beta_{38 i} \\ \beta_{41 i} \beta_{42 i} \beta_{43 i} \beta_{44 i} \beta_{45 i} \beta_{46 i} \beta_{47 i} \beta_{48 i} \\ \beta_{51 i} \beta_{52 i} \beta_{53 i} \beta_{54 i} \beta_{55 i} \beta_{56 i} \beta_{57 i} \beta_{58 i} \\ \beta_{61 i} \beta_{62 i} \beta_{63 i} \beta_{64 i} \beta_{65 i} \beta_{66 i} \beta_{67 i} \beta_{68 i} \\ \beta_{71 i} \beta_{72 i} \beta_{73 i} \beta_{74 i} \beta_{75 i} \beta_{76 i} \beta_{77 i} \beta_{78 i} \\ \beta_{81 i} \beta_{82 i} \beta_{83 i} \beta_{84 i} \beta_{85 i} \beta_{86 i} \beta_{87 i} \beta_{88 i}\end{array}\right] \times\left[\begin{array}{c}L C O 2_{t-i} \\ L P_{t-i} \\ L S_{t-i} \\ L S V_{t-i} \\ L V S_{t-i} \\ L W B P_{t-i} \\ L W C_{t-i} \\ L W F_{t-i}\end{array}\right]+$ $\left[\begin{array}{l}\theta_{1} \\ \theta_{2} \\ \theta_{3} \\ \theta_{4} \\ \theta_{5} \\ \theta_{6} \\ \theta_{7} \\ \theta_{8}\end{array}\right]\left[E C T_{t-1}\right]+\left[\begin{array}{l}\varepsilon_{1 t} \\ \varepsilon_{2 t} \\ \varepsilon_{3 t} \\ \varepsilon_{4 t} \\ \varepsilon_{5 t} \\ \varepsilon_{6 t} \\ \varepsilon_{7 t} \\ \varepsilon_{8 t}\end{array}\right]$

Where $L C O 2$ denotes the dependent variable, $L P, L S, L S V, L V S, L W B P, L W C$ and $L W F$ are the explanatory variables in year $t, \Delta$ represents the difference operator, $E C T_{t-1}$ represents the error correction term resulting from the long-run co-integration relationship, $\theta$ 's, $\alpha$ 's and $\beta$ 's are the parameters to be estimated, $p$ represents the number of lags and $\varepsilon_{t}$ 's are the serially independent error terms.

Following the work of Asumadu-Sarkodie and Owusu [10],Asumadu-Sarkodie and Owusu [12],Ozturk and Acaravci [17],Asumadu-Sarkodie and Owusu [18], the ARDL model for this study is expressed as:

$$
\begin{aligned}
& \Delta L C O 2_{t}=\alpha_{0}+\delta_{1} L C O 2_{t-1}+\delta_{2} L P_{t-1}+\delta_{3} L S_{t-1}+\delta_{4} L S V_{t-1}+\delta_{5} L V S_{t-1}+ \\
& \delta_{6} L W B P_{t-1}+\delta_{7} L W C_{t-1}+\delta_{8} L W F_{t-1}+\sum_{i=1}^{p} \beta_{1} \Delta L C O 2_{t-i}+\sum_{i=0}^{p} \beta_{2} \Delta L P_{t-i}+
\end{aligned}
$$




$$
\begin{aligned}
& \sum_{i=0}^{p} \beta_{3} \Delta L S_{t-i}+\sum_{i=0}^{p} \beta_{4} \Delta L S V_{t-i}+\sum_{i=0}^{p} \beta_{5} \Delta L V S_{t-i}+\sum_{i=0}^{p} \beta_{6} \Delta L W B P_{t-i}+ \\
& \sum_{i=0}^{p} \beta_{7} \Delta L W C_{t-i}+\sum_{i=0}^{p} \beta_{8} \Delta L W F_{t-i}+\varepsilon_{t}
\end{aligned}
$$

Where $\alpha$ denotes the intercept, $p$ represents the lag order, $\varepsilon_{t}$ represents the error term and $\Delta$ represents the first difference operator. In order to estimate the long-run equilibrium relationship in the ARDL Bounds approach, the study employs the F-tests statistic based on the null hypothesis of no co-integration between LCO2, LP, LS, LSV, LVS, LWBP, LWC and LWF $\left[H_{0}: \delta_{1}=\delta_{2}=\delta_{3}=\delta_{4}=\delta_{5}=\delta_{6}=\delta_{7}=\delta_{8}=0\right.$ ], against the alternative hypothesis of co-integration between LCO2, LP, LS, LSV, LVS, LWBP, LWC and LWF $\left[H_{1}: \delta_{1} \neq \delta_{2} \neq\right.$ $\left.\delta_{3} \neq \delta_{4} \neq \delta_{5} \neq \delta_{6} \neq \delta_{7} \neq \delta_{8} \neq 0\right]$. Accordingly, the null hypothesis of no cointegration between LCO2, LP, LS, LSV, LVS, LWBP, LWC and LWF is rejected if the estimated Fstatistic goes above the critical value of the upper bound. Nevertheless, the null hypothesis is cannot be rejected if the estimated F-statistic goes below the critical value of the lower bound [19]. 


\section{Results and Discussion}

\section{Vector Error Correction Model}

Table 4 shows the VAR Lag order selection criteria used in the study. Evidence from Table 4 shows that the optimal lag selected by the selection criteria (LR, FPE, AIC, SC and HQ) for the Johansen test of co-integration is indicated by “*”.

Table 4. Lag Selection Criteria

\begin{tabular}{lllllll}
\hline Lag & LogL & LR & FPE & AIC & SC & HQ \\
\hline 0 & -15.4644 & NA & $3.41 \mathrm{E}-10$ & 0.9025 & 1.202667 & 1.017562 \\
1 & 320.6782 & 555.9281 & $9.97 \mathrm{E}-15$ & -9.5645 & $-6.8628^{*}$ & $-8.5288^{*}$ \\
2 & 402.1967 & $109.7364^{*}$ & $6.03 \mathrm{e}-15^{*}$ & $-10.2383^{*}$ & -5.1351 & -8.2819 \\
\hline
\end{tabular}

* indicates lag order selected by the criterion

LR: sequential modified LR test statistic (each test at 5\% level)

FPE: Final prediction error

AIC: Akaike information criterion

SC: Schwarz information criterion

HQ: Hannan-Quinn information criterion

Using the optimal lag selected, the Johansen co-integration test [20] employs the maxeigenvalue and trace methods for the unrestricted co-integration rank tests presented in Table 5. Evidence from Table 5 shows that the the null hypothesis of no co-integration is rejected at $5 \%$ significance level, indicating 3 co-integrating equations. 
Table 5. Johansen Method of Co-integration

\begin{tabular}{|c|c|c|c|c|c|c|c|}
\hline $\begin{array}{l}\text { Hypothesized } \\
\text { No. of CE(s) }\end{array}$ & Eigenvalue & $\begin{array}{l}\text { Trace } \\
\text { Statistic }\end{array}$ & $\begin{array}{l}5 \% \text { Critical } \\
\text { Value }\end{array}$ & Prob.** & $\begin{array}{l}\text { Max- } \\
\text { Eigen } \\
\text { Statistic }\end{array}$ & $\begin{array}{l}5 \% \text { Critical } \\
\text { Value }\end{array}$ & Prob.** \\
\hline None * & 0.7884 & 246.0016 & 159.5297 & 0.0000 & 79.1993 & 52.3626 & 0.0000 \\
\hline At most $1 *$ & 0.6838 & 166.8023 & 125.6154 & 0.0000 & 58.7279 & 46.2314 & 0.0015 \\
\hline At most $2 *$ & 0.5584 & 108.0744 & 95.7537 & 0.0054 & 41.6900 & 40.0776 & 0.0326 \\
\hline At most 3 & 0.3969 & 66.3844 & 69.8189 & 0.0911 & 25.7914 & 33.8769 & 0.3336 \\
\hline At most 4 & 0.3122 & 40.5930 & 47.8561 & 0.2020 & 19.0874 & 27.5843 & 0.4078 \\
\hline At most 5 & 0.2082 & 21.5056 & 29.7971 & 0.3269 & 11.9079 & 21.1316 & 0.5568 \\
\hline At most 6 & 0.1523 & 9.5977 & 15.4947 & 0.3130 & 8.4249 & 14.2646 & 0.3371 \\
\hline At most 7 & 0.0227 & 1.1728 & 3.8415 & 0.2788 & 1.1728 & 3.8415 & 0.2788 \\
\hline
\end{tabular}

Trace and Max-Eigen test indicates 3 cointegrating eqn (s) at the 5\% level

* denotes rejection of the hypothesis at the $5 \%$ level

**MacKinnon-Haug-Michelis (1999) p-values

The 3 co-integrating equations are used to estimate the VECM as showed in Table 6. Evidence from Table 6 shows that the error correction term [_ce1 L1.=-0.73] is negative and significant at 5\% level, showing evidence of a long-run equilibrium relationship running from LP, LS, LSV, LVS, LWBP, LWC and LWF to LCO2. Results in Table 6 indicates that LP $\left[\_c e 1\right.$ L1. $\left.=0.52, \rho=0.11\right]$, LS [_ce1 L1. $\left.=0.08, \rho=0.74\right]$, LSV [_ce1 L1. $=-0.29, \rho=$ 0.28], LWBP [_ce1 L1. $=0.01, \rho=0.97$ ] and LWF [_ce1 L1. $=0.00, \rho=0.96$ ] are not significant at 5\% level. However, the relationship between LVS [_ce1 L1. $=1.47, \rho=0.04]$ and LCO2 is positive and significant at 5\% level. The implication is that, a $1 \%$ increase in veneer sheet production reduces carbon dioxide emissions by $1.47 \%$ in the long-run. Veneer sheet production tend to affect carbon dioxide emissions positively since its one of the most environmentally efficient and economically feasible ways of producing timber.

The relationship between LWC [_ce1 L1. $=0.18, \rho=0.00]$ and LCO2 is positive and significant at $5 \%$ level. The implication is that, a $1 \%$ increase in wood charcoal production reduces carbon dioxide emissions by $0.18 \%$ in the long-run. 
Table 6. Vector Error Correction Model

\begin{tabular}{|c|c|c|c|c|c|}
\hline & & Coef. & Std. Err. & $\mathrm{z}$ & $\mathrm{P}>|\mathrm{z}|$ \\
\hline \multicolumn{6}{|l|}{$\mathrm{LCO} 2$} \\
\hline & _ce1 L1. & -0.7346 & 0.1615 & -4.5500 & 0.0000 \\
\hline & ce2 L1. & 0.1997 & 0.0617 & 3.2400 & 0.0010 \\
\hline & ce3 L1. & 0.0985 & 0.1006 & 0.9800 & 0.3280 \\
\hline & cons & 0.0660 & 0.0181 & 3.6500 & 0.0000 \\
\hline \multicolumn{6}{|l|}{ LP } \\
\hline & _ce1 L1. & 0.5156 & 0.3181 & 1.6200 & 0.1050 \\
\hline & cee2 L1. & -0.2793 & 0.1215 & -2.3000 & 0.0220 \\
\hline & ce3 L1. & -0.3275 & 0.1981 & -1.6500 & 0.0980 \\
\hline & _cons & 0.0495 & 0.0356 & 1.3900 & 0.1650 \\
\hline \multicolumn{6}{|l|}{ LS } \\
\hline & _ce1 L1. & 0.0815 & 0.2472 & 0.3300 & 0.7420 \\
\hline & ce 2 L1. & 0.1419 & 0.0944 & 1.5000 & 0.1330 \\
\hline & ce3 L1. & -0.4549 & 0.1540 & -2.9500 & 0.0030 \\
\hline & cons & -0.0375 & 0.0277 & -1.3600 & 0.1750 \\
\hline \multicolumn{6}{|l|}{ LSV } \\
\hline & _ce1 L1. & -0.2886 & 0.2679 & -1.0800 & 0.2810 \\
\hline & ce2 L1. & 0.1481 & 0.1023 & 1.4500 & 0.1480 \\
\hline & _ce3 L1. & 0.0889 & 0.1669 & 0.5300 & 0.5940 \\
\hline & cons & 0.0024 & 0.0300 & 0.0800 & 0.9370 \\
\hline \multicolumn{6}{|l|}{ LVS } \\
\hline & _ce1 L1. & 1.4732 & 0.7297 & 2.0200 & 0.0430 \\
\hline & _ce2 L1. & 0.1819 & 0.2787 & 0.6500 & 0.5140 \\
\hline & ce3 L1. & 1.0213 & 0.4545 & 2.2500 & 0.0250 \\
\hline & cons & 0.0113 & 0.0817 & 0.1400 & 0.8900 \\
\hline \multicolumn{6}{|l|}{ LWBP } \\
\hline & _ce1 L1. & 0.0118 & 0.2970 & 0.0400 & 0.9680 \\
\hline & ce2 L1. & 0.1711 & 0.1135 & 1.5100 & 0.1320 \\
\hline & _ce3 L1. & -0.3588 & 0.1850 & -1.9400 & 0.0520 \\
\hline & cons & 0.0381 & 0.0332 & 1.1500 & 0.2520 \\
\hline \multicolumn{6}{|l|}{ LWC } \\
\hline & _ce1 L1. & 0.1863 & 0.0618 & 3.0100 & 0.0030 \\
\hline & ce2 L1. & -0.0935 & 0.0236 & -3.9600 & 0.0000 \\
\hline & ce3 L1. & -0.0846 & 0.0385 & -2.2000 & 0.0280 \\
\hline & cons & 0.0511 & 0.0069 & 7.3900 & 0.0000 \\
\hline \multicolumn{6}{|l|}{ LWF } \\
\hline & _ce1 L1. & 0.0037 & 0.0696 & 0.0500 & 0.9580 \\
\hline & _ce2 L1. & 0.0774 & 0.0266 & 2.9100 & 0.0040 \\
\hline & _ce3 L1. & -0.0459 & 0.0433 & -1.0600 & 0.2900 \\
\hline & cons & 0.0238 & 0.0078 & 3.0500 & 0.0020 \\
\hline
\end{tabular}




\section{VECM Diagnostic Test}

In order to have a robust result, the study examines the independence of the residuals in the VECM. Table 7 presents the diagnostic test for the VECM. Evidence from the Jarque-Bera test in Table 7 shows that the null hypothesis of normal distribution cannot be rejected at $5 \%$ significance level. The null hypothesis of no serial correlation at lag order h by the Lagrangemultiplier test cannot be rejected at 5\% significance level. The null hypothesis of no ARCH effect by the Heteroskedasticity Test cannot be rejected at 5\% significance level. Evidence from Table 7 shows that the residuals in the VECM are normally distributed, have no problems with serial correlation and have a constant variance.

Fig. 2 presents the inverse root of characteristics polynomial to check the stability of the VECM. Evidence from Fig. 2 shows that the eigenvalues of the respective matrix is less than 1 with no unit root outside the unit circle, confirming the VECM satisfying the VAR stability conditions. 
Table 7. Diagnostic Tests for VECM

\begin{tabular}{llll}
\hline Jarque-Bera Test & \multicolumn{3}{l}{} \\
\hline Component & Jarque-Bera & $\mathrm{df}$ & Prob. \\
1 & 0.1573 & 2 & 0.9244 \\
2 & 1.2149 & 2 & 0.5447 \\
3 & 5.7851 & 2 & 0.0554 \\
4 & 1.9128 & 2 & 0.3843 \\
5 & 3.1884 & 2 & 0.2031 \\
6 & 0.6676 & 2 & 0.7162 \\
7 & 4.0196 & 2 & 0.1340 \\
8 & 1.6314 & 2 & 0.4423 \\
Joint & 18.5771 & 16 & 0.2912 \\
Heteroskedasticity Test: ARCH & & \\
F-statistic & 0.145921 & Prob. & 0.7041 \\
\multicolumn{4}{l}{ VEC Residual Serial Correlation LM Tests } \\
Lags & LM-Stat & & \\
1 & 64.2820 & & Prob \\
2 & 66.5907 & & 0.4666 \\
3 & 62.9680 & & 0.3879 \\
\hline
\end{tabular}

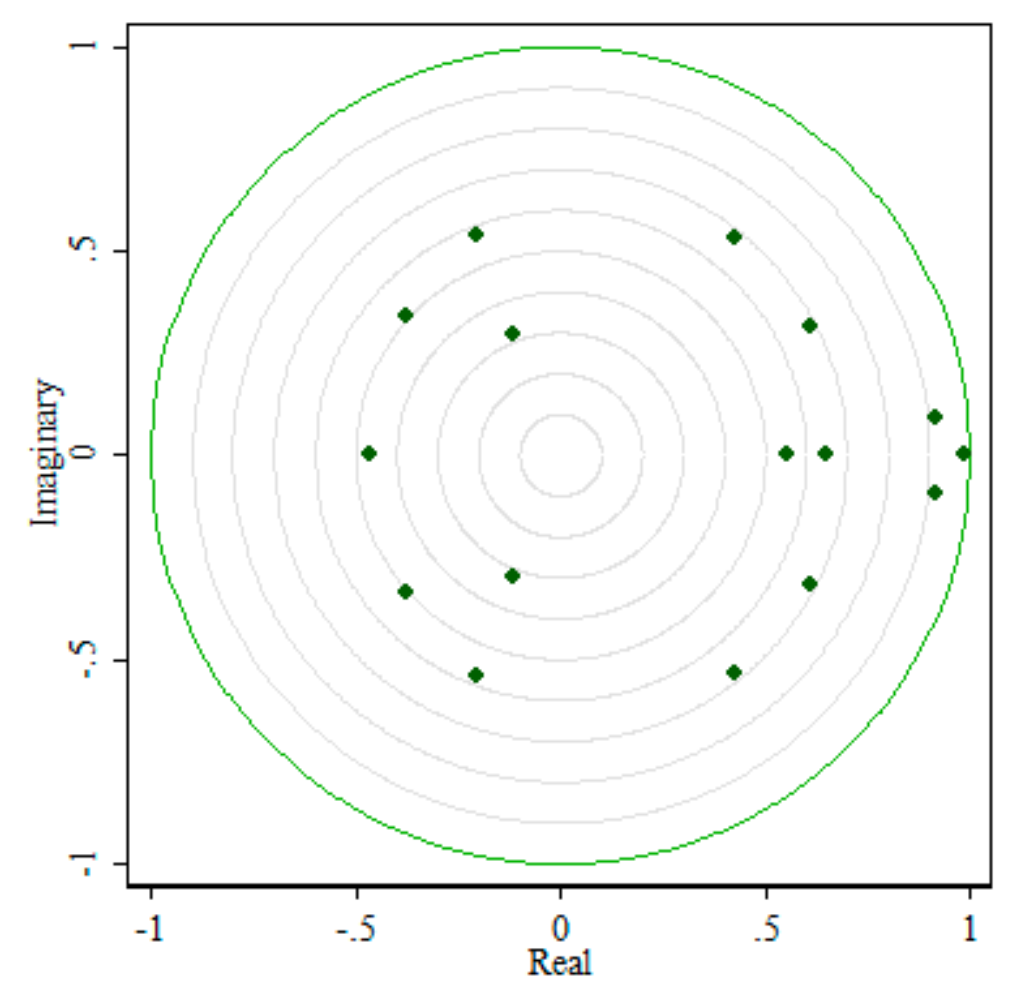

Fig. 2. Roots of Characteristic Polynomial 


\section{Granger-Causality}

The VECM reveals the existence of a long-run equilibrium relationship between variables but fails to indicate the direction of the causal relationship. As such, the study employs the Grangercausality test [21] to ascertain the causal relationships between LCO2, LP, LS, LSV, LVS, LWBP, LWC and LWF. Table 8 presents the results of the Granger causality tests based on VECM. The null hypothesis that LCO2 does not Granger cause LVS, LCO2 does not Granger cause LWC, LCO2 does not Granger cause LWF, LP does not Granger cause LCO2, LVS does not Granger cause LCO2, and LWC does not Granger cause LEU is rejected at the significance level indicated with '*' in Table 8 . Accordingly, there is a bidirectional causality between LCO2 and LVS, LCO2 and LWC, and a unidirectional causality running from LCO2 to LWF and LP to LCO2. Evidence from the joint Granger-causality shows a unidirectional causality from LCO2 to all the variables (LP, LS, LSV, LVS, LWBP, LWC and LWF).

Table 8. Granger causality Wald tests

\begin{tabular}{lllll}
\hline Equation & Excluded & chi $^{2}$ & df & Prob $>$ chi $^{2}$ \\
\hline LCO2 & LP & 3.8010 & 2 & 0.1490 \\
LCO2 & LS & 0.2331 & 2 & 0.8900 \\
LCO2 & LSV & 2.1706 & 2 & 0.3380 \\
LCO2 & LVS & 12.6180 & 2 & $0.0020^{*}$ \\
LCO2 & LWBP & 1.6777 & 2 & 0.4320 \\
LCO2 & LWC & 20.1670 & 2 & $0.0000^{*}$ \\
LCO2 & LWF & 5.1510 & 2 & $0.0760^{* *}$ \\
LCO2 & ALL & 45.4180 & 14 & $0.0000^{*}$ \\
LP & LCO2 & 5.8097 & 2 & $0.0550^{* *}$ \\
LS & LCO2 & 2.9963 & 2 & 0.2240 \\
LSV & LCO2 & 3.2747 & 2 & 0.1940 \\
LVS & LCO2 & 17.3820 & 2 & $0.0000^{*}$ \\
LWBP & LCO2 & 2.3876 & 2 & 0.3030 \\
LWC & LCO2 & 7.0300 & 2 & $0.0300^{*}$ \\
LWF & LCO2 & 2.5745 & 2 & 0.2760 \\
$*$ ** rejection of the null hypothesis at 5 and 10\% significance level
\end{tabular}




\section{ARDL Regression Model}

The study estimates the ARDL regression model and the bounds co-integration test proposed by Pesaran et al. [19]. Table 9 presents the results of the ARDL Bounds test in order to ascertain the co-integration relationship between the variables. Evidence from Table 9 shows that the Fstatistic lies above the $10 \%, 2.5 \%$ and $1 \%$ critical values of the I1 Bound, rejecting the null hypothesis of no co-integration relationship.

Table 9. ARDL Bounds Test

\begin{tabular}{lll}
\hline Test Statistic & Value & $\mathrm{k}$ \\
$\begin{array}{l}\text { F-statistic } \\
\text { Critical Value Bounds }\end{array}$ & 4.54 & 7 \\
Significance & & \\
$10 \%$ & I0 Bound & I1 Bound \\
$5 \%$ & 1.92 & 2.89 \\
$2.50 \%$ & 2.17 & 3.21 \\
$1 \%$ & 2.43 & 3.51 \\
\hline
\end{tabular}

From the evidence of co-integration, the study employs the Akaike information criterion to select an optimal model [Selected Model: $\operatorname{ARDL}(2,1,0,2,2,0,1,0)$ ] for the ARDL regression analysis as showed in Fig. 3. 


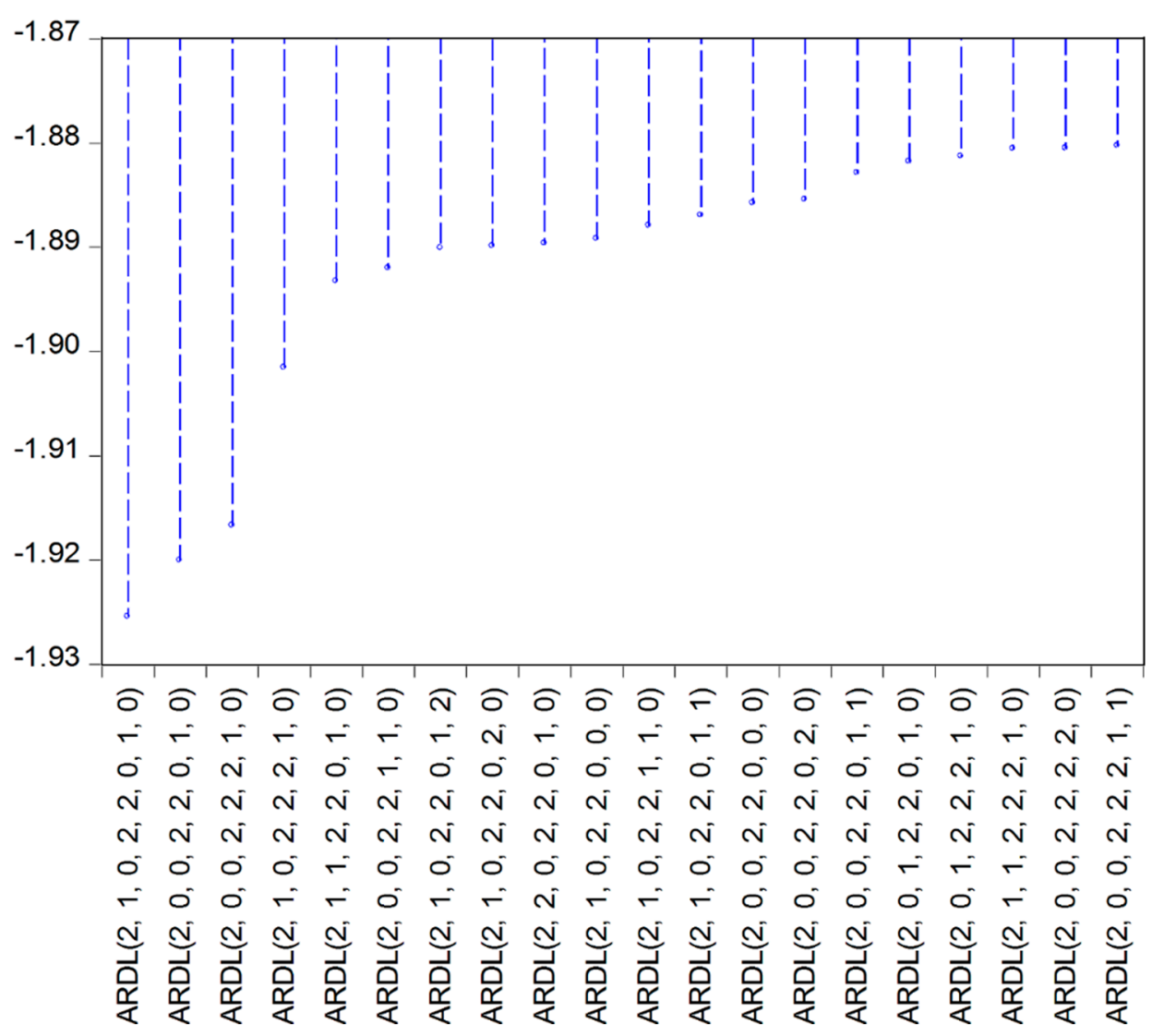

Fig. 3. ARDL Model Selection Criterion

Using the optimal model [Selected Model: ARDL $(2,1,0,2,2,0,1,0)]$, the study estimates the ARDL regression analysis. The normalized co-integration equation for the ARDL Model is expressed as:

Cointeq $=\mathrm{LCO} 2-(0.1661 * \mathrm{LP}+0.1678 * \mathrm{LS}-0.0102 * \mathrm{LSV}+0.0122 * \mathrm{LVS}-$ $0.0764 * \mathrm{LWBP}+0.3639 * \mathrm{LWC}+0.3710 * \mathrm{LWF}-5.7651)$

Table 10 presents an estimation of the ARDL regression. Table 10 shows that the error correction term $[\operatorname{ECT}(-1)=-0.72]$ is negative and significant at $5 \%$ level, showing evidence of a long-run equilibrium relationship running from LP, LS, LSV, LVS, LWBP, LWC and LWF to LCO2.

Evidence from the short-run estimation in Table 10 shows that; a $1 \%$ increase in LP will increase LCO2 by $0.19 \%$ in the short-run, a $1 \%$ increase in LS will increase LCO2 by $0.26 \%$ 
in the short-run, a $1 \%$ increase in LWC will increase $\mathrm{LCO} 2$ by $1.14 \%$ in the short-run and a $1 \%$ increase in LWF will increase $\mathrm{LCO} 2$ by $0.63 \%$ in the short-run.

Evidence from the long-run estimation in Table 10 shows that; a $1 \%$ increase in LP will increase LCO2 by $0.17 \%$ in the long-run, a $1 \%$ increase in LS will increase LCO2 by $0.17 \%$ in the long-run, a $1 \%$ increase in LWC will increase $\mathrm{LCO} 2$ by $0.36 \%$ in the long-run and a $1 \%$ increase in LWF will increase LCO2 by $0.37 \%$ in the long-run.

Table 10. ARDL Regression Analysis

\begin{tabular}{|c|c|c|c|c|}
\hline Variable & Coefficient & Std. Error & t-Statistic & Prob. \\
\hline \multicolumn{5}{|c|}{ Short-Run Estimation } \\
\hline LP & 0.1927 & 0.0693 & 2.7818 & 0.0086 \\
\hline LS & 0.2565 & 0.0687 & 3.7331 & 0.0007 \\
\hline LSV & 0.0639 & 0.0655 & 0.9762 & 0.3355 \\
\hline LVS & 0.0506 & 0.0229 & 2.2090 & 0.0336 \\
\hline LWBP & -0.1113 & 0.0768 & -1.4492 & 0.1559 \\
\hline LWC & 1.1367 & 0.1849 & 6.1484 & 0.0000 \\
\hline LWF & 0.6308 & 0.1839 & 3.4300 & 0.0015 \\
\hline $\operatorname{ECT}(-1)$ & -0.7156 & 0.2142 & -8.0106 & 0.0000 \\
\hline \multicolumn{5}{|c|}{ Long-Run Estimation } \\
\hline Variable & Coefficient & Std. Error & t-Statistic & Prob. \\
\hline LP & 0.1661 & 0.0426 & 3.8973 & 0.0004 \\
\hline LS & 0.1678 & 0.0542 & 3.0965 & 0.0038 \\
\hline LSV & -0.0102 & 0.0414 & -0.2456 & 0.8074 \\
\hline LVS & 0.0122 & 0.0206 & 0.5928 & 0.5571 \\
\hline LWBP & -0.0764 & 0.0571 & -1.3389 & 0.1890 \\
\hline LWC & 0.3639 & 0.0605 & 6.0189 & 0.0000 \\
\hline LWF & 0.3710 & 0.0704 & 5.2705 & 0.0000 \\
\hline $\mathrm{C}$ & -5.7651 & 0.5688 & -10.1351 & 0.0000 \\
\hline
\end{tabular}




\section{ARDL Diagnostic Test}

Table 11 presents a diagnostic tests of the ARDL regression analysis. Evidence from Table 11 shows that the null hypothesis of no heteroskedasticity by the Breusch-Pagan-Godfrey test cannot be rejected at 5\% significance level. The null hypothesis of no serial correlation by the Breusch-Godfrey LM test cannot be rejected at 5\% significance level. The null hypothesis of normal distribution by the Jarque-Bera test cannot be rejected at 5\% significance level and the null hypothesis of no omitted variables in the model by the Ramsey RESET Test cannot be rejected at 5\% significance level. In summary, the residuals in the ARDL model have no problems with heteroskedasticity, have no problems with serial correlation, are normally distributed and have a constant variance.

Table 11. ARDL Diagnostic Test

\begin{tabular}{|c|c|c|c|}
\hline \multicolumn{4}{|c|}{ Heteroskedasticity Test: Breusch-Pagan-Godfrey } \\
\hline F-statistic & 0.623382 & Prob. $\mathrm{F}(15,36)$ & 0.8361 \\
\hline \multicolumn{4}{|c|}{ Breusch-Godfrey Serial Correlation LM Test: } \\
\hline $\begin{array}{l}\text { F-statistic } \\
\text { Jarque-Bera }\end{array}$ & 1.23028 & Prob. F(2,34) & 0.3049 \\
\hline Jarque-Bera & 1.4953 & Prob. & 0.4735 \\
\hline \multicolumn{4}{|c|}{ Ramsey RESET Test } \\
\hline F-statistic & 0.007839 & Prob. $F(1,35)$ & 0.93 \\
\hline
\end{tabular}

Figs. 4-5 show the CUSUM and CUSUM of Squares tests of the ARDL model to check the constancy of the co-integration space. In Figs. 4-5, the plots in the CUSUM and CUSUM of Squares tests lie within the 5\% significance level, which provide evidence of a stable and robust ARDL model. 


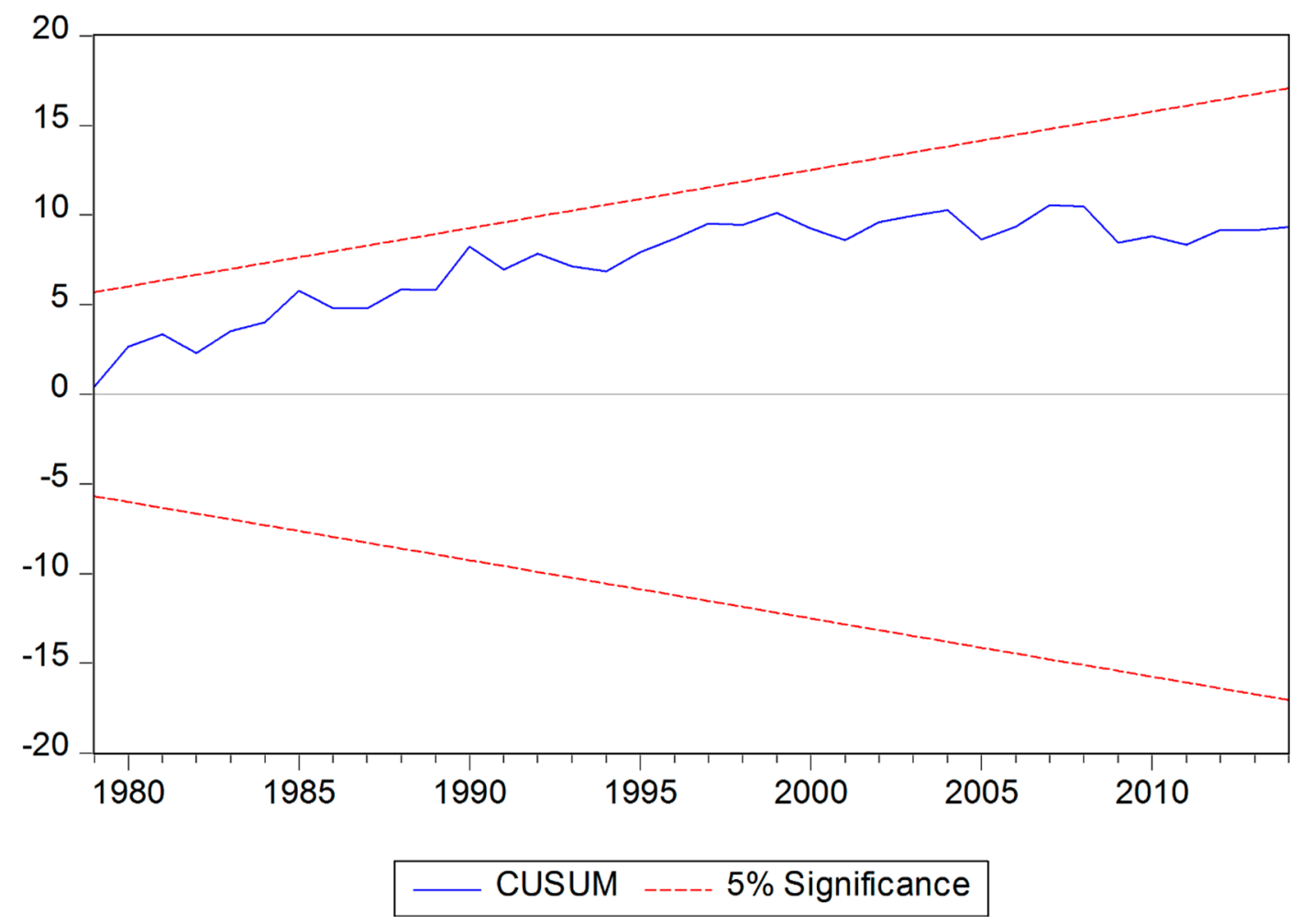

Fig. 4. CUSUM of Residuals

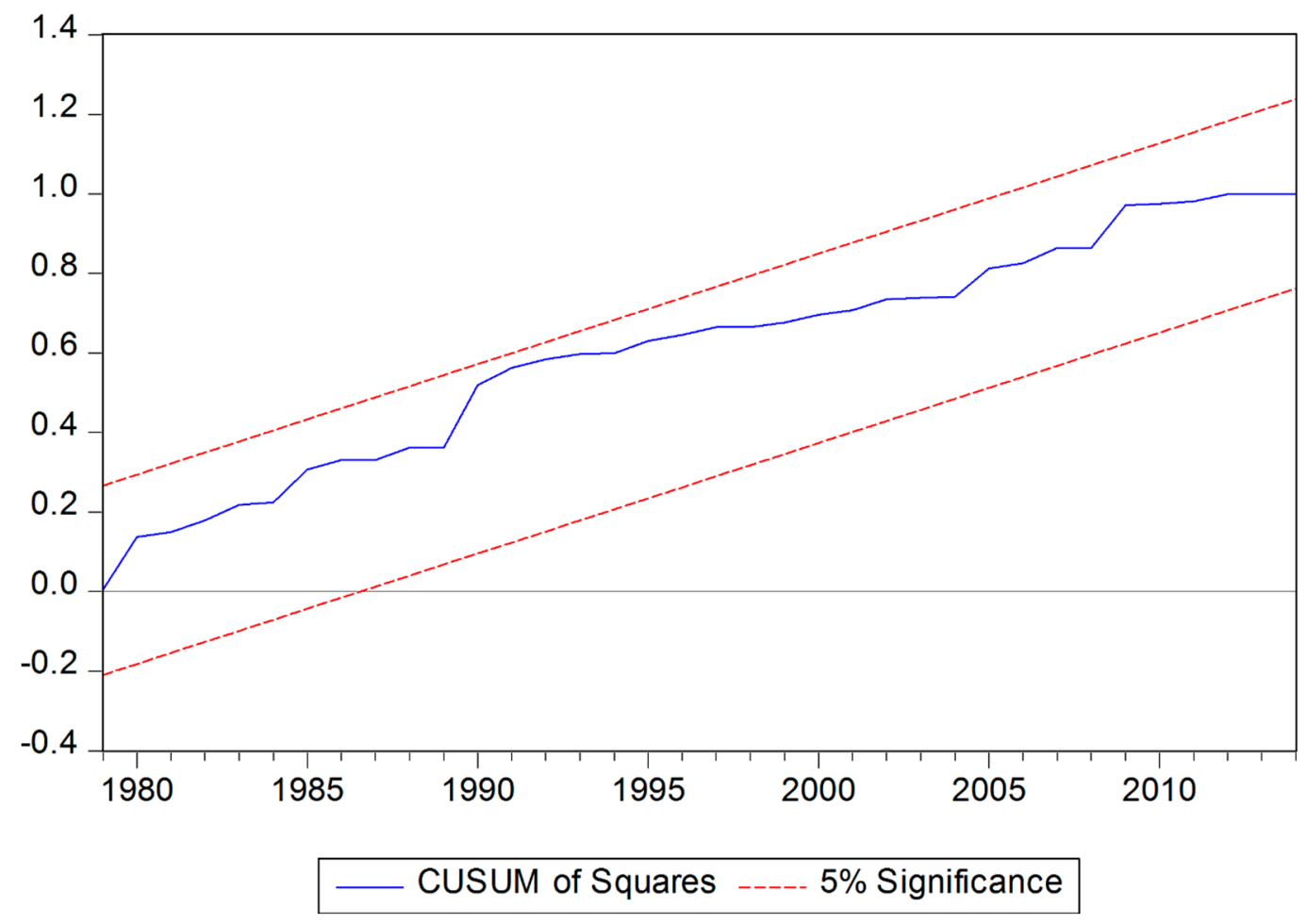

Fig. 5. CUSUM of Squares Residuals 


\section{Conclusion and Policy Recommendation}

The study examined the causal-effect between carbon dioxide emissions and forestry production and trade: a case study in Ghana by employing a data spanning from 1961 to 2014 by using the VECM and ARDL model. Both the VECM and ARDL model showed evidence of a long-run equilibrium relationship between the variables. Evidence from the long-run equilibrium relationship in the VECM shows that, a $1 \%$ increase in veneer sheet production reduces carbon dioxide emissions by $1.47 \%$ in the long-run. Veneer sheet production tend to affect carbon dioxide emissions positively since its one of the most environmentally efficient and economically feasible ways of producing timber. There was evidence of a long-run equilibrium relationship between wood charcoal production and carbon dioxide emissions. The implication is that, a $1 \%$ increase in wood charcoal production reduces carbon dioxide emissions by $0.18 \%$ in the long-run. Even though charcoal production is a very delicate issue in many countries, nevertheless, wood charcoal production in Ghana tends to affect carbon dioxide emissions positively since it yields a health-dividend, a reduced smoke levels compared to fossil-fuel based resources and cleaner combustion.

There was evidence of a bidirectional causality between carbon dioxide emissions and veneer sheets production, carbon dioxide emissions and wood charcoal production, and a unidirectional causality running from carbon dioxide emissions to wood fuel production and plywood production to carbon dioxide emissions.

Evidence from the short-run equilibrium relationship in the ARDL model shows that; a $1 \%$ increase in plywood production will increase carbon dioxide emissions by $0.19 \%$ in the shortrun, a $1 \%$ increase in sawnwood production will increase carbon dioxide emissions by $0.26 \%$ in the short-run, a $1 \%$ increase in wood charcoal production will increase carbon dioxide emissions by $1.14 \%$ in the short-run and a $1 \%$ increase in wood fuel production will increase carbon dioxide emissions by $0.63 \%$ in the short-run. 
Evidence from the long-run equilibrium relationship in the ARDL model shows that; a $1 \%$ increase in plywood production will increase carbon dioxide emissions by $0.17 \%$ in the longrun, a $1 \%$ increase in sawnwood production will increase carbon dioxide emissions by $0.17 \%$ in the long-run, a $1 \%$ increase in wood charcoal production will increase carbon dioxide emissions by $0.36 \%$ in the long-run and a $1 \%$ increase in wood fuel production will increase carbon dioxide emissions by $0.37 \%$ in the long-run.
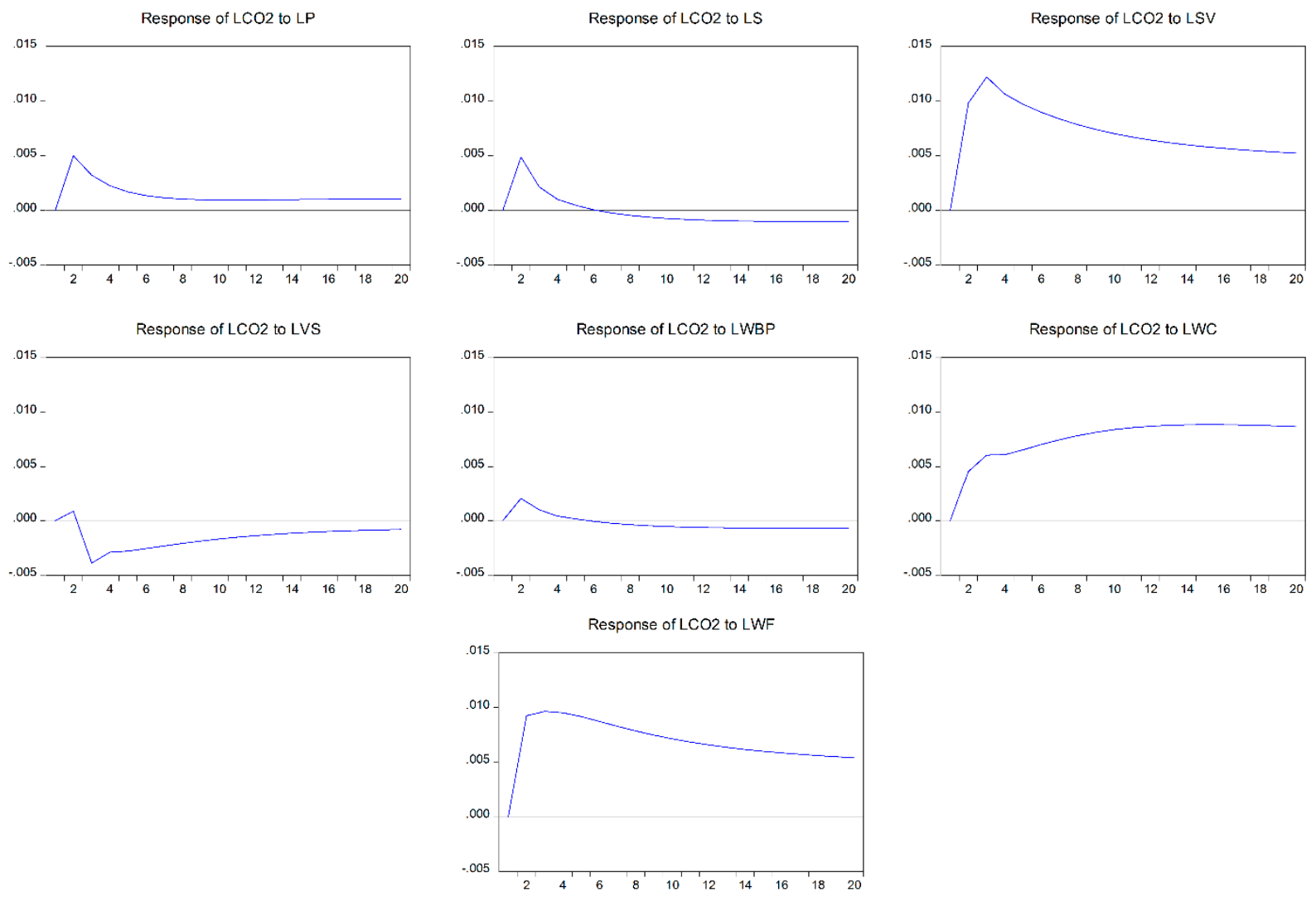

Response to Cholesky One S.D. Innovations

Fig. 6. Response of LCO2 to Cholesky One S.D. Innovations in other Variables

Evidence from Fig. 6 shows that a one standard deviation shock to veneer sheets, sawnwood and wood-based panels production increases carbon dioxide emissions to 2-period horizon and die-off over the 3-period horizon. In addition, a one standard deviation shock to plywood, sawlogs \& veneer logs and wood fuel production increases carbon dioxide emissions to 2period horizon and decreases gradually with time. However, a one standard deviation shock to 
wood charcoal production increases carbon dioxide emissions over the period horizon. Contrary to the VECM, the impulse-response confirms the evidence provided by the ARDL model. Wood charcoal production in Ghana tends to increase carbon dioxide emissions in the short-run and long-run which has policy implications for Ghana. Wood charcoal production has over the years been associated with illegal chainsaw operation, a rampant corruption, poor and inefficient conversion technologies in the charcoal industry, deforestation and degradation which affects air quality, health and environmental sustainable. Nevertheless, since wood charcoal production constitutes $60 \%$ of Ghana's energy supply for heating and cooking $[1,2,9]$, renewable-source fuels and highly efficient kilns can be utilized to make the production more environmentally friendly.
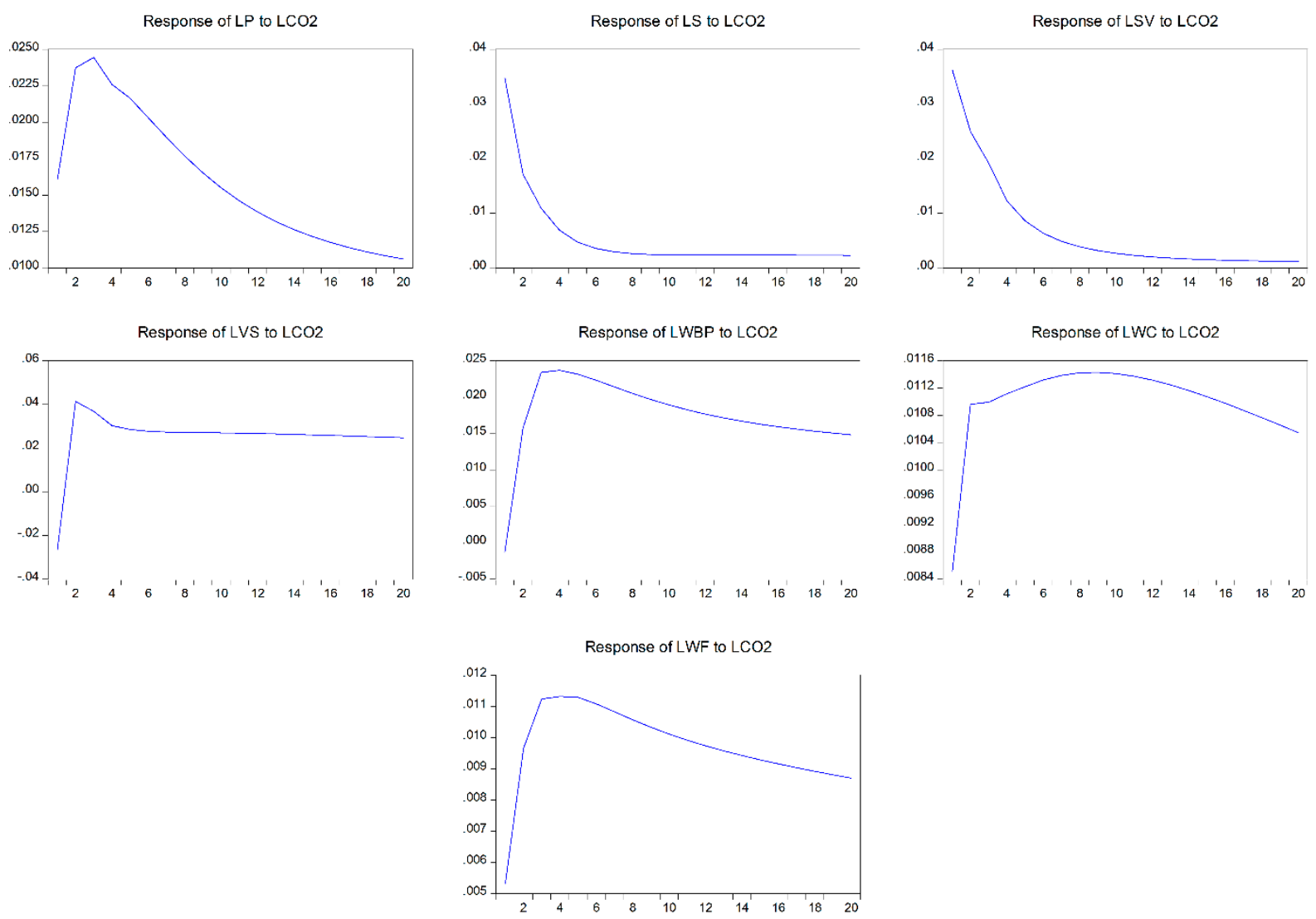

Fig. 7. Response of other Variables to Cholesky One S.D. Innovations in LCO2 
Evidence from Fig. 7 shows that a one standard deviation shock to carbon dioxide emissions increases plywood, sawnwood, sawlogs \& veneer logs, veneer sheets, wood-based panels, wood charcoal and wood fuel production carbon dioxide emissions to 2-period horizon and decreases over the given period which has a policy implication for Ghana. Evidence from the study shows that if carbon dioxide emission levels in Ghana are not mitigated, Ghana's forest reserve will decline with time which will lead to a lot of environmental hazards such as heat waves, change in weather patterns, poor air quality leading to health hazards and a destroyed ecosystem.

As a policy recommendation, the Government of Ghana should institute public timber procurement policies that ensures re-planting of trees to replaced extinct ones. There is the need for the creation of new job opportunities that displaces the illegal chainsaw operation in Ghana. There is the need for an establishment of code of conduct for the lumber industry and enhanced capacity of the Forest Commission of Ghana to monitor the forest regularly. It is essential for the Government of Ghana to incorporate climate change mitigation options into the forest policies, by creating awareness, providing early warnings, climate change adaptations and institutional capacity building.

\section{References}

1. Owusu P, Asumadu-Sarkodie S (2016) A Review of Renewable Energy Sources, Sustainability Issues and Climate Change Mitigation. Cogent Engineering 3: 1167990.

2. Owusu PA, Asumadu-Sarkodie S, Ameyo P (2016) A review of Ghana's water resource management and the future prospect. Cogent Engineering 3: 1164275.

3. Asumadu-Sarkodie S, Owusu PA (2016) The potential and economic viability of wind farms in Ghana. Energy Sources, Part A: Recovery, Utilization, and Environmental Effects 38: 695-701.

4. Asumadu-Sarkodie S, Owusu PA (2016) The potential and economic viability of solar photovoltaic power in Ghana. Energy Sources, Part A: Recovery, Utilization, and Environmental Effects 38: 709-716. 
5. Asumadu-Sarkodie S, Owusu PA (2016) Feasibility of biomass heating system in Middle East Technical University, Northern Cyprus Campus. Cogent Engineering 3: 1134304.

6. Asumadu-Sarkodie S, Sevinç Ç, Jayaweera HMPC (2016) A Hybrid Solar PhotovoltaicWind Turbine-Rankine Cycle for Electricity Generation in Turkish Republic Of Northern Cyprus. Cogent Engineering 3: 1180740.

7. UN-REDD (2016) About REDD+.

8. Ghanaweb (2014) Illegal chainsaw operators make \$200m annually.

9. Asumadu-Sarkodie S, Owusu P (2016) A Review of Ghana's Energy Sector National Energy Statistics and Policy Framework. Cogent Engineering 3: 1155274.

10. Asumadu-Sarkodie S, Owusu PA (2016) Carbon dioxide emissions, GDP, energy use and population growth: a multivariate and causality analysis for Ghana, 1971-2013. Environ Sci Pollut Res Int.

11. Asumadu-Sarkodie S, Owusu PA (2016) Multivariate co-integration analysis of the Kaya factors in Ghana. Environ Sci Pollut Res Int 23: 9934-9943.

12. Asumadu-Sarkodie S, Owusu PA (2016) The relationship between carbon dioxide and agriculture in Ghana: a comparison of VECM and ARDL model. Environ Sci Pollut Res Int.

13. FAO (2015) FAO Statistical Yearbooks - World food and agriculture.

14. Dickey DA, Fuller WA (1979) Distribution of the estimators for autoregressive time series with a unit root. Journal of the American statistical association 74: 427-431.

15. Phillips PC, Perron P (1988) Testing for a unit root in time series regression. Biometrika 75: $335-346$.

16. Vogelsang TJ, Perron P (1998) Additional tests for a unit root allowing for a break in the trend function at an unknown time. International Economic Review: 1073-1100.

17. Ozturk I, Acaravci A (2011) Electricity consumption and real GDP causality nexus: Evidence from ARDL bounds testing approach for 11 MENA countries. Applied Energy 88: 2885-2892.

18. Asumadu-Sarkodie S, Owusu P (2016) The Casual Nexus between Child Mortality Rate, Fertility Rate, GDP, Household Final Consumption Expenditure and Food Production Index. Cogent Economics \& Finance.

19. Pesaran MH, Shin Y, Smith RJ (2001) Bounds testing approaches to the analysis of level relationships. Journal of applied econometrics 16: 289-326.

20. Johansen S (1995) Likelihood-based inference in cointegrated vector autoregressive models. OUP Catalogue.

21. Granger CW (1988) Some recent development in a concept of causality. Journal of econometrics 39: 199-211.

(C) 2016 by the authors; licensee Preprints, Basel, Switzerland. This article is an open access article distributed under the terms and conditions of the Creative Commons by Attribution (CC-BY) license (http://creativecommons.org/licenses/by/4.0/). 